\title{
Investment and Saving Nexus in Asian Countries: Panel Cointegration and Causality
}

\author{
Mohsen Mehrara ${ }^{1, *}$, Maysam Musai ${ }^{2, * *}$ \\ ${ }^{1}$ Faculty of Economics, University of Tehran, Kargar-e-shomali \\ Po Box 14166-6445, Tehran, Iran \\ ${ }^{2}$ Faculty of Social Sciences, University of Tehran, Tehran, Iran \\ *,*E-mail address: mmehrara@ut.ac.ir , mousai@ut.ac.ir
}

\begin{abstract}
This paper investigates the causal relationship between gross domestic investment (INV) and saving rates for 40 Asian countries by using panel unit root tests and panel cointegration analysis for the period 1970-2010. The results indicate no long run relationship as well as no causalities between these two variables in these countries. The findings are attributed to non stationary deficits or surpluses in current accounts.
\end{abstract}

Keywords: Panel Unit Root; Panel Cointegration; Granger Causality; Gross Domestic Investment (INV); Saving; Asian countries

JEL classifications: C22; F21; F32; F36

\section{INTRODUCTION}

The relationship between saving and investment has been a serious challenge in the empirical literature following the pioneering work of Feldstein and Horioka (1980). They have examined the relationship between savings and investment in 23 industrialized countries for the period 1960-1974 and indicated high correlation between these two variables. They indicated that the estimated regression coefficient, or the saving-retention coefficient, were near to unity, indicating that most of the incremental saving remain in the country of origin. Their result was a dilemma in a world of increasing capital mobility and persistent current account imbalances. Indeed, according to their hypothesis, with perfect capital mobility, there should be no relation between domestic saving and domestic investment.

From a policy point of view, it is important to know the direction of causality between investment and saving. Does the growth of the saving rate cause the growth of the investment rate Or does the causality run in the reverse direction. Nowadays, the usual understanding is that government fiscal imbalances deficits are not desirable due to their undesirable macroeconomic effects. At the back of this view of government fiscal imbalances is the idea that saving causes investment, and because government deficits is considered as negative government saving, this decreases the amount of saving available for investment and thereby hinders economic growth. According to this view, low saving rates in some developing countries force them to an uncomfortable choice between low investment and growth, or 
extreme reliance on foreign capital which makes them vulnerable to foreign crises. If causality runs from saving to investment, then the reduction of the deficits by cutting government expenditure rather than by increasing tax is essential. This is a more cautious policy because increasing taxes decreases disposable income and saving, reducing the impact of lower deficits on national saving. On the other hand, if investment causes saving, then there are no merits of cutting government spending or the budget deficit. Indeed, if the causality runs from investment to saving, policy measures should shift away from saving-promoting policies and be employed to achieve sustainable growth through more productivity.

Many studies have attempted to solve the Feldstein-Horioka puzzle by examining relationship between saving and investment rates, empirically in different countries. Yamori (1995) examined the relationship between two variables for Japan for the period 1970-1985 using ordinary least squares (OLS) and two-stage least squares (2SLS). The results showed that there is no correlation between savings and investment implying perfect capital mobility. Arginon and Roldan (1994) studied the saving-investment relationship in EU countries during the period 1960-1988, and indicated unidirectional causality running from saving to investment. Apergis and Tsoulfidis (1997) used the ARDL bounds testing approach to cointegration to $14 \mathrm{EU}$ countries. They found a cointegrating relationship between saving and investment, and that saving Granger causes investment. De and Eyden (2005) applying panel data for 36 sub Saharan African countries including Ethiopia found an evidence of high capital mobility. They concluded that the foreign aid and FDI flows (and not the domestic saving) determine investment ratio in these countries. In most of the studies, the saving retention coefficient was found to be high for developed countries while, the low coefficient for developing countries has been interpreted as high capital mobility in these countries.

Afzal (2007) studied relationship between savings and investment in developing countries using cointegration techniques. He indicates there is no long-run relationship between savings and investment in seven countries of the sample, implying high degree of capital mobility and failing of savings and investment relationship. He find evidence of bidirectional causality between savings and investment in South Africa, and unidirectional causality from savings to investment in Pakistan and Sri Lanka, with no causality in India, Philippines, Malaysia, and Iran. However, he says the strong correlation between savings and investment does not rule out capital mobility across these countries. Esso and Keho (2010) have found some evidence of the absence of causality between savings and investment for West African Economic and Monetary Union (UEMOA) countries that has been attributed to capital mobility. On the other hand, Onafowara et al. (2011) investigated the relationship between savings and investment in eight advanced economies of the European Union and found evidence of cointegration for six countries. Sanjib and Joice (2012) examined the relationship between savings and investment in three economies, namely, US, UK, China and India. They showed a cointegrating relationship between savings and investment in these countries. Adebola and Dahalan (2012) studied the relationship between savings and investment for Tunisia during the period 1970-2009 based on Autoregressive Distributed Lag (ARDL) Model and Granger causality test. They found the existence of long run relationship when investment is taken as dependent variable. The results of Granger causality test indicated two-way causality validating the low capital mobility as suggested by FH hypothesis.

The focus of the paper is, therefore, to examine the relationship between between gross domestic investment and saving rates in sample 40 Asian countries for the period 1970-2010. The direction of causality between these two variables is examined by utilizing a cointegration and error correction modeling framework. The paper is organized in four sections. Section 2 discusses the methodology, data and empirical results of the study. Section 3 concludes. 


\section{DATA AND EMPIRICAL RESULTS}

We apply a two variable model to examine the causal relationship between investment and saving as \% GDP. Data used in the analysis are annual time series during the period 19702010 on (logarithm of) real gross domestic investment (INV) and gross domestic saving rate (SAVING) for 40 Asian countries. The data are obtained from Asian Development Bank (ADB) and World Development Indicators (WDI) 2011, published by the World Bank. The choice of the starting period was constrained by the availability of data. The countries considered in this study are Armenia, Azerbaijan, Georgia, Kazakhstan, Kyrgyz Republic, Pakistan, Tajikistan, Turkmenistan, Uzbekistan, China People's Rep. of, Hong Kong; China, Korea Rep., Mongolia, Bangladesh, Bhutan, India, Maldives, Nepal, Sri Lanka, Brunei Darussalam, Cambodia, Indonesia, Lao PDR, Malaysia, Philippines, Singapore, Thailand, Viet Nam, Fiji Islands, Kiribati, Marshall Islands, Palau, Papua New Guinea, Samoa, Solomon Islands, Tonga, Vanuatu, Australia, Japan, New Zealand

To test the nature of association between the variables while avoiding any spurious correlation, the empirical investigation in this paper follows the three steps: We begin by testing for non-stationarity in the variables of INV and SAVING. Prompted by the existence of unit roots in the time series, we test for long run cointegrating relation between variables at the second step of estimation using the panel cointegration technique developed by Pedroni (1995, 1999). Granted the long run relationship, we explore the causal link between the variables by testing for granger causality at the final step.

\section{1. Panel Unit Roots Results}

The panel data technique referred above has appealed to the researchers because of its weak restrictions. It captures country specific effects and allows for heterogeneity in the direction and magnitude of the parameters across the panel. In addition, it provides a great degree of flexibility in model selection. Following the methodology used in earlier works in the literature we test for trend stationarity of the variables of INV and SAVING. With a null of non-stationary, the test is a residual based test that explores the performance of four different statistics. Together, these four statistics reflect a combination of the tests used by Levin-Lin (1993) and Im, Pesaran and Shin (1997). While the first two statistics are non-parametric rhostatistics, the last two are parametric ADF t-statistics. Sets of these four statistics have been reported in Table 1.

The first two rows report the panel unit root statistics for INV and SAVING at the levels. As we can see in the table, we cannot reject the unit-root hypothesis when the variables are taken in levels and thus any causal inferences from the series in levels are invalid. The last two rows report the panel unit root statistics for first differences of INV and SAVING. The large negative values for the statistics indicate rejection of the null of non-stationary at $1 \%$ level for all variables. It may, therefore be concluded that the variables of INV and SAVING are unit root variables of order one, or, I(1) for short.

Table 1. Test of Unit Roots for INV and SAVING.

\begin{tabular}{ccccc}
\hline Variables & $\begin{array}{c}\text { Levin-Lin } \\
\text { Rho-stat }\end{array}$ & $\begin{array}{c}\text { Levin-Lin } \\
\text { t-Rho-stat }\end{array}$ & $\begin{array}{c}\text { Levin-Lin } \\
\text { ADF stat }\end{array}$ & IPS ADF stat \\
\hline
\end{tabular}

$\begin{array}{lllll}I N V & 1.44 & -1.71 & -1.72 & -1.90\end{array}$




\begin{tabular}{ccccc} 
SAVING & -1.86 & -1.77 & -1.69 & -1.19 \\
$\triangle I N V$ & $-14.63^{*}$ & $-10.92^{*}$ & $-11.39^{*}$ & $-18.41^{*}$ \\
$\triangle$ SAVING & $-15.65^{*}$ & $-11.52^{*}$ & $-15.54^{*}$ & $-17.61^{*}$ \\
\hline *
\end{tabular}

*significant at $1 \%$

\section{2. Panel Cointegration Results}

At the second step of our estimation, we look for a long run relationship among INV and SAVING using the panel cointegration technique developed by Pedroni $(1995,1999)$. This technique is a significant improvement over conventional cointegration tests applied on a single country series. While pooling data to determine the common long run relationship, it allows the cointegrating vectors to vary across the members of the panel. The cointegration relationship we estimate is specified as follows:

$$
I N V_{i t}=\alpha_{i}+\delta_{t}+\beta_{i} S A V I N G_{i t}+\varepsilon_{i t}
$$

where $\alpha_{i}$ refers to country effects and $\delta_{t}$ refers to trend effects. $\varepsilon_{i t}$ is the estimated residual indicating deviations from the long run relationship. With a null of no cointegration, the panel cointegration test is essentially a test of unit roots in the estimated residuals of the panel. Pedroni (1999) refers to seven different statistics for this test. Of these seven statistics, the first four are known as panel cointegration statistics; the last three are group mean panel cointegration statistics. In the presence of a cointegrating relation, the residuals are expected to be stationary. These tests reject the null of no cointegration when they have large negative values except for the panel-v test which reject the null of cointegration when it has a large positive value. All of these seven statistics under different model specifications are reported in Table 2. The statistics for all different model specifications fail to reject of the null of no cointegration for all tests. We, therefore, conclude that the variables INV and SAVING are not cointegrated in the long run.

Table 2. Results of Panel Cointegration test.

\begin{tabular}{cc}
\hline Statistics & \\
\hline Panel v-stat & 1.32 \\
Panel Rho-stat & -1.02 \\
Panel PP-stat & -0.89 \\
Panel ADF-stat & -0.94 \\
Group Rho-stat & -0.88 \\
Group PP-stat & -1.31 \\
Group ADF-stat & -1.65 \\
\hline
\end{tabular}

\section{3. Panel Causality Results}

Non-Cointegration implies lack of long run causality between the series but it does not rule out short-run causality. Moreover, the direction of the short run causal relationship is not concerned in cointegration test. With a rejection of long run equilibrium relationship among 
INV and SAVING, we test for Granger causality in the short run at the third and final step of estimation. The short run dynamic model of our interest by is specified as follows:

$$
\begin{aligned}
& \Delta S A V I N G_{i t}=\alpha_{S i}+\gamma_{S 1 i} \Delta I N V_{i t-1}+\gamma_{S 2 i} \Delta I N V_{i t-2}+ \\
& \delta_{S 1 i} \Delta S A V I N G_{i t-1}+\delta_{S 2 i} \Delta S A V I N G_{i t-1}+\varepsilon_{S i t} \\
& \Delta I N V_{i t}=\alpha_{I i}+\gamma_{I 1 i} \Delta I N V_{i t-1}+\gamma_{I 2 i} \Delta I N V_{i t-2}+ \\
& \delta_{I 1 i} \Delta S A V I N G_{i t-1}+\delta_{I 2 i} \Delta S A V I N G_{i t-1}+\varepsilon_{l i t}
\end{aligned}
$$

where $\Delta$ is a difference operator; and the $\varepsilon_{S i t}$ and $\varepsilon_{\text {Iit }}$ are disturbance terms assumed to be uncorrelated with mean zero.

The direction of short run causation can be identified by testing for significance of the coefficients on the lagged variables in Eqs (2) and (3). First, by testing $H_{0}: \gamma_{S 1 i}=\gamma_{S 2 i}=0$ for all $\mathrm{i}$ in Eq. (2) or $H_{0}: \delta_{I 1 i}=\delta_{I 2 i}=0$ for all $\mathrm{i}$ in Eq. (3), we evaluate weak Granger causality. Masih and Masih (1996) and Asafu-Adjaye (2000) interpreted the weak Granger causality as 'short run' causality in the sense that the dependent variable responds only to short-term shocks to the stochastic environment. As there is no long run relationship, the second possible source of (long run) causation through error correction term is absent. Indeed, the coefficients on the ECTs are set to zero at the test equation (2) and (3) (Hatanaka, 1996). So, short run noncausality implies absence of both short and long run causalities.

The results of the F test are reported in Table 3. The results indicate that there is no causation between savings and investment both the short- and long-run in either direction in these countries. The lack of causality between savings and investment can be attributed to the varying deficits and surplus of the current account in most of these countries.

Table 3. Result of Panel causality tests.

\begin{tabular}{ccc}
\hline & \multicolumn{2}{c}{ Short-run causality } \\
\cline { 2 - 3 } Dependent Variable & $\Delta$ SAVING & $\Delta \mathrm{INV}$ \\
\hline$\Delta$ SAVING & - & $\mathrm{F}=1.04$ \\
$\Delta \mathrm{INV}$ & $\mathrm{F}=1.81$ & - \\
\hline
\end{tabular}

\section{CONCLUSION}

The objective of this study is to examine Granger causality between investment and saving rates (as \% GDP) 40 Asian countries over the period 1970-2010. The panel integration and cointegration techniques are employed to investigate the relationship between the variables. The empirical results indicate that we cannot find enough evidence against the null hypothesis of unit root. However, for the first difference of the variables, we rejected the null hypothesis of unit root. It means that the variables are I(1). The results show the absence of long-run relationship between investment and saving, ruling out long run causality between 
two variables. In some of the empirical studies including Feldstein and Horioka (1980), the absence of correlation between savings and investment is attributed to the high degree of capital mobility, which is not the case for most of this group of countries. Possibly, non stationary deficit or surpluses in current accounts render some reason to this finding.

\section{Acknowledgements}

The authors would like to acknowledge the financial support of University of Tehran for this research under the grant number 4401012/1/22.

\section{References}

[1] Adebole S. S., Dahalan J., International Journal of Economics and Financial Issues 2(1) (2012) 1-11.

[2] Afzal M., Philippine Review of Economics 44(2) (2007) 34-44.

[3] Agrawal P. (2000). Savings, Investment and Growth in South Asia. Indira Gandhi Institute of Development Research.

[4] Apergis N., Tsoulfidis L., Research in Economics 51 (1997) 333-358.

[5] Argimon I., Roldan J. M., European Economic Review 38 (1994) 59-67.

[6] De Long J. B., L. Summers, Quarterly Journal of Economics CVI (1991) 445-502.

[7] Esso L., J. Keho, International Journal of Economics and Finance 17 (2010) 174-181.

[8] Feldstein M., C. Horioka, The Economic Journal 90 (1980) 314-329.

[9] Asafu-Adjaye J., Energy Economics 22 (2000) 615-625.

[10] Granger C. W. J., Econometrica 37(3) (1969) 424-438.

[11] Granger C. W. J., Journal of Econometrics 39 (1988) 199-211.

[12] Harrod R. F., Economic Journal 49 (1939) 14-33.

[13] Hatanaka M., (1996). Time-Series-Based Econometrics: Unit Roots and Co-integration. Oxford University Press, Oxford.

[14] Im K. S., Pesaran M. H., Shin Y. (1997). Testing for Unit Roots in Heterogeneous Panels, University of Cambridge, Department of Applied Economics.

[15] Im K. S., Pesaran M. H., Shin Y., Journal of Econometrics 115 (2003) 53-74.

[16] Levin A., Lin C. F., (1992). Unit Root Tests in Panel Data: Asymptotic and Finite Sample Properties. Department of Economics, University of California at San Diego, Working Paper 92-23.

[17] Levin A., Lin C. F., (1993). Unit Root Test in Panel Data: New Results. Department of Economics, University of California, San Diego, Working paper 93-56.

[18] Levin A., Lin C. F., Chu C. S. J., Journal of Econometrics 108 (2002) 1-24.

[19] Masih A. M. M., Masih, R., Energy Economics 18 (1995)165-183. 
[20] Pedroni P. (1995). Panel Cointegration: Asymptotic and Finite Sample Properties of Pooled Time Series Tests, with an Application to the PPP Hypothesis. Indiana University, Working Papers in Economics, No. 95-013.

[21] Pedroni P. (1997). Panel Cointegration: Asymptotic and Finite Sample Properties of Pooled Time Series Tests, with an Application to the PPP Hypothesis: New results, India University, Working Papers in Economics.

[22] Pedroni P., Oxford Bulletin of Economics and Statistics 61(4) (1999) 5-49.

[23] Pedroni P., Econometric Theory 20(3) (2004) 597-627.

[24] Pesaran M. H., Shin Y., (1997). An Autogressive Distributed Lag Modelling Approach to Cointegration Analysis, Working Paper Trinity College, Cambridge.

[25] Solow R. M., Journal of Economics 70 (1956) 65-94.

[26] Yamori N., Economics Letters 48 (1995) 361-366. 